\title{
膀胱運動に対するジスチグミンの長時間持続性増強効果の作用機序について
}

\author{
小原圭将, ${ }^{*}$ 田中芳夫
}

\section{Mechanism of the Long-lasting Potentiating Effect of Distigmine on Urinary Bladder Motility}

\author{
Keisuke Obara* and Yoshio Tanaka \\ Department of Chemical Pharmacology, Faculty of Pharmaceutical Sciences, \\ Toho University; 2-2-1 Miyama, Funabashi, Chiba 274-8510, Japan.
}

(Received September 15, 2020; Accepted October 13, 2020)

\begin{abstract}
Distigmine bromide (distigmine) is a carbamate cholinesterase (ChE) inhibitor, which is mainly used for the treatment of myasthenia gravis. Distigmine is also used in Japan for the treatment for underactive bladder and glaucoma. The effectiveness of distigmine for underactive bladder treatment has been confirmed by many clinical reports, and this effect is thought to be caused by potentiating urinary bladder smooth muscle contraction due to inhibition of acetylcholine degradation during micturition. However, the pharmacological effects of distigmine on urinary bladder smooth muscle have not been well studied. The most distinctive pharmacological feature of distigmine is that it shows long-lasting effects than other $\mathrm{ChE}$ inhibitors; however, few studies have investigated the persistence of the enhancing effect of distigmine on the contractile function of urinary bladder smooth muscle. Moreover, this mechanism remains unclear. In this review, we present our findings on the mechanism of the potentiating effect of distigmine on isolated guinea pig urinary bladder smooth muscle contraction. We also discuss the long-lasting potentiating effect of distigmine on urinary bladder motility and the mechanism of these effects using guinea pig urinary bladder smooth muscle in vivo and in vitro. In addition, we present our investigations on the long-lasting mechanism of distigmine using recombinant human acetylcholinesterase.
\end{abstract}

Key words__ distigmine bromide; urinary bladder smooth muscle; cholinesterase; acetylcholine; ATP; cystometry

\section{1.はじめに}

ジスチグミン臭化物（ジスチグミン）は，1950 年代に Schmid により合成されたカルバメート系コ リンエステラーゼ (cholinesterase; ChE) 阻害薬で あり, 1) ジスチグミンと同様カルバメート系 $\mathrm{ChE}$ 阻 害薬に分類されるピリドスチグミンをへキサメチレ ン基を介して 2 分子含有する化学構造をとる（Fig. 1). ジスチグミンの主たる適応は，ピリドスチグミ ン，ネオスチグミン，アンベノニウムなどの他の ChE 阻害薬 (Fig. 1) と同様, 重症筋無力症であり, 日本国内のほか, アジア，中東，欧州で臨床使用さ れている. ${ }^{2-5)}$ また，ジスチグミンは，日本では， 緑内障治療薬としても使用されている. ${ }^{6-8)}$ さら に，日本において，ジスチグミンは，1968 年の発 売以降，尿排出機能障害（低活動膀胱）に対する治

東邦大学薬学部薬理学教室（干274-8510 千葉県船橋市 三山 2-2-1)

*e-mail: keisuke.obara@phar.toho-u.ac.jp
療薬として重要な地位を占めている，具体的には， ジスチグミンは，手術後や糖尿病などの慢性疾患に 付随して発症する神経因性の低活動膀胱に伴う尿排 出機能障害に対して治療効果を示すことが報告され ており，欧州でもその有効性が報告されてい る. ${ }^{9-21)}$ 薬剤性尿排出機能障害や前立腺肥大による 排尿障害に対する使用実績も報告されており, ${ }^{22-26)}$ これらの臨床成績は，ジスチグミンの尿排出機能障 害に対する有効性と有用性を示している.

ジスチグミンが尿排出機能障害に対して発揮され る有効な治療効果は, 膀胱平滑筋の収縮力増強作用 によりもたらされると推察されていた。しかし，臨 床成績の報告はなされていたものの，その標的とな る膀胱平滑筋での薬理作用や作用機序はほとんど検 討されていなかった．また，ジスチグミンの薬理作 用の最大の特徵として, 他の ChE 阻害薬と比較し て，その作用が持続的であることが挙げられるが, ジスチグミンによる膀胱平滑筋の収縮力の増強効果 に関する持続性については，不明のままであつた。 
<smiles>CN(CCCCCCN(C)C(=O)Oc1ccc[n+](C)c1)C(=O)Oc1ccc[n+](C)c1</smiles><smiles>CN(C)C(=O)Oc1ccc[n+](C)c1</smiles>

Pyridostigmine<smiles>CN(C)C(=O)Oc1cccc([N+](C)(C)C)c1</smiles>

Neostigmine<smiles>CC[N+](CC)(CCNC(=O)C(=O)NCC[N+](CC)(CC)Cc1ccccc1Cl)Cc1ccccc1Cl</smiles>

Ambenonium

Fig. 1. Structures of Carbamate Cholinesterase Inhibitors (distigmine, pyridostigmine, neostigmine, and ambenonium)

さらに，ジスチグミンの長時間持続性の性質が何に よってもたらされるのかという点も未解決のままで あった．本総説では，われわれが報告した膀胱平滑 筋での副交感神経伝達物質による収縮反応に対する ジスチグミンの作用及びその作用機序について概説 するとともに，モルモットの摘出膀胱平滑筋標本や 生体位膀胱標本に対するジスチグミンの長時間持続 性の性質についても紹介する。ささら，その長時間 持続性の機序について，リコンビナントヒトアセチ ルコリンエステラーゼ (recombinant human acetylcholinesterase; rhAChE) を用いて検討した結果も あわせて紹介する.

2. 副交感神経の興奮を介した膀胱平滑筋の収縮 反応に対するジスチグミンの影響

排尿時の膀胱では，副交感神経が興奮し，その神 経終末よりアセチルコリン（acetylcholine; ACh） とATP が遊離されることが知られている. ${ }^{27)}$ ジス チグミンは, 膀胱平滑筋のアセチルコリンエステ ラーゼ (acetylcholinesterase; AChE) を阻害するこ とが報告されていたため, ${ }^{28)}$ ジスチグミンが膀胱平 滑筋の AChE を阻害することで, 副交感神経-排尿 筋のシナプス間隙での $\mathrm{ACh}$ を増加させることによ り膀胱平滑筋の収縮力を増強すると推定されてい た.ここでは, この推定を裏付けるために行ったモ ルモット摘出膀胱平滑筋の経壁電気刺激（electrical field stimulation; EFS) による副交感神経の興奮を 介した収縮反応に対するジスチグミンの効果に関す
るわれわれの検討結果を紹介する. ${ }^{29)}$

$\mathrm{ACh}$ 成分と ATP 成分を区別するため，プリン受 容体の脱感作薬である $\alpha, \beta$-methylene ATP $(\alpha, \beta$ mATP $)\left(10^{-4} \mathrm{M}\right)$ 存在下で ACh を介した収縮成 分に対するジスチグミンの影響を検討したところ， ジスチグミン $\left(10^{-6} \mathrm{M}\right)$ は， $\alpha, \beta$-mATP $\left(10^{-4} \mathrm{M}\right)$ 存在下で誘発された EFS による収縮反応を非常に 強力に増強した [Fig. 2(A)]。この増強された収縮 成分は，ムスカリン受容体拮抗薬である atropine $\left(10^{-6} \mathrm{M}\right)$ の処置によりほぼ完全に消失したことか ら，ジスチグミンが副交感神経の興奮により遊離さ れた ACh による収縮反応を増強することが示され た. ${ }^{29)}$ また， ジスチグミン $\left(3 \times 10^{-8}-3 \times 10^{-6} \mathrm{M}\right)$ が外因性 ACh によるモルモット摘出膀胱平滑筋の 収縮反応を濃度依存的に増強することも確認し た. ${ }^{30-32)}$ さらに，バルーン法を用いて， ACh (1.0 $\mathrm{mg} / \mathrm{kg}$ ) を静脈内投与 (intravenous injection; i.v.) した際の生体位モルモットの膀胱内圧変化を測定 し，ジスチグミン非投与下では膀胱内圧に変化を与 えないが，ジスチグミン $(0.03-1.0 \mathrm{mg} / \mathrm{kg}$, i.v. $)$ 投 与下では膀胱内圧を上昇させることも見い出し た. ${ }^{32)}$

一方，ジスチグミンは，ATPを介した収縮成分 に対しては影響を与えなかった [Fig. 2(B) ]. ${ }^{29)}$ さ らに，ジスチグミン $\left(10^{-6} \mathrm{M}\right)$ は，外因性 ATPに よるモルモット摘出膀胱平滑筋の収縮反応に対して も影響を与えないことを確認した. ${ }^{33)}$ なお，マウス 

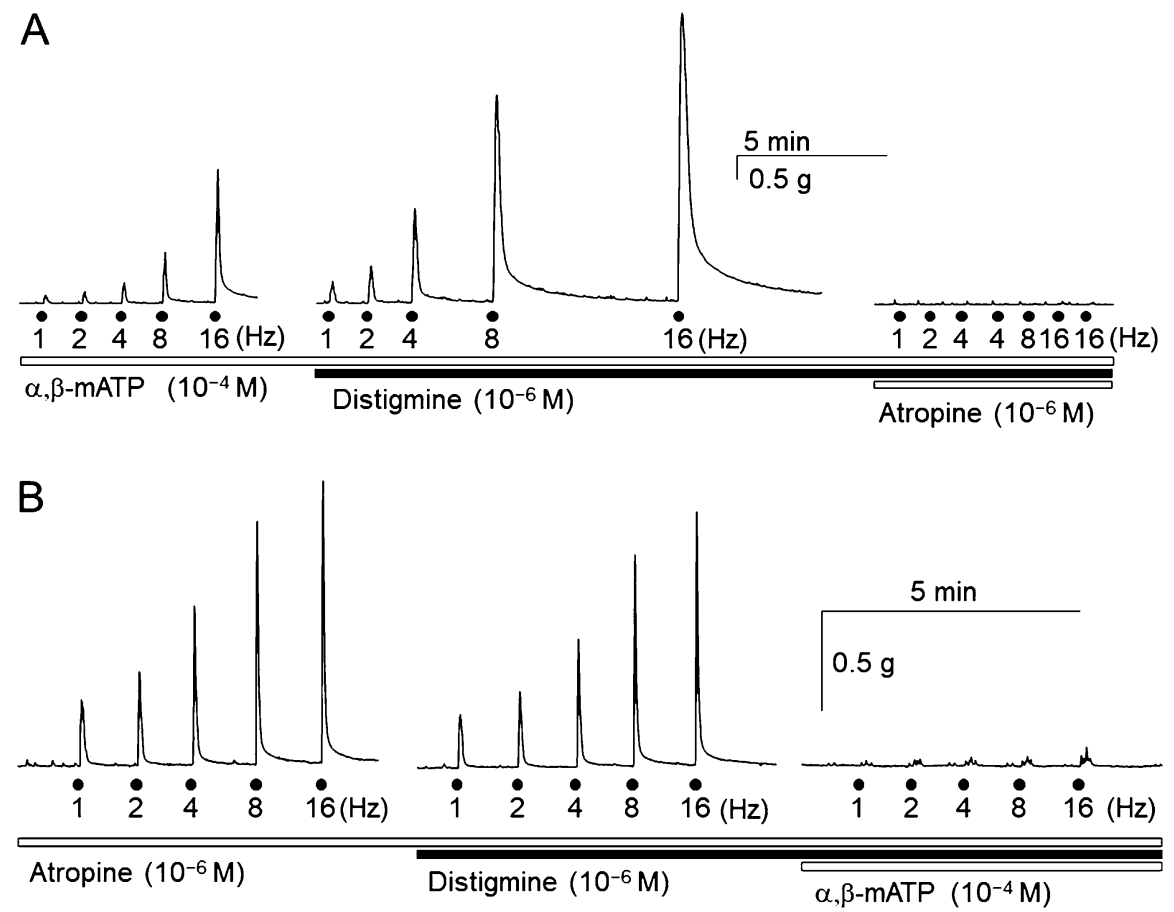

Fig. 2. Effects of Distigmine on Electrical Field Stimulation (EFS) -induced Contractions of Guinea Pig Urinary Bladder Smooth Muscle

(A) Representative traces of the potentiating effects of distigmine $\left(10^{-6} \mathrm{M}\right)$ on EFS-induced contractions in the presence of $\alpha, \beta$-methylene ATP $(\alpha, \beta$-mATP, $\left.10^{-4} \mathrm{M}\right)$. (B) Representative traces of the effects of distigmine $\left(10^{-6} \mathrm{M}\right)$ on EFS-induced contractions in the presence of atropine $\left(10^{-6} \mathrm{M}\right)$. All experiments were carried out in the presence of phentolamine $\left(10^{-6} \mathrm{M}\right)$, propranolol $\left(10^{-6} \mathrm{M}\right)$, and indomethacin $\left(3 \times 10^{-6} \mathrm{M}\right)$. These data were reproduced with permission from Eur. J. Pharmacol., 809, 209-214. Copyright 2017 Elsevier.

膀胱平滑筋でも EFS による収縮反応に対するジス チグミンの効果を検討したが，モルモット膀胱平滑 筋と同様に ACh を介した収縮成分を選択的に増強 することも確認した. ${ }^{34)}$

したがって，これらの事実から，先ほどの副交感 神経一排尿筋のシナプス間隙での $\mathrm{ACh}$ を増加させ ることにより膀胱平滑筋の収縮力を増強するという 推定は正しいと考えられた.

3. モルモットの膀胱機能に対するジスチグミン の効果と血漿中濃度との関係性

ジスチグミンによる ChE 阻害作用は可逆的では あるものの，その作用は長時間にわたり持続するこ とが開発初期から指摘されてきた。この長時間持続 性の性質は，ジスチグミンの最も特徵的な薬理学的 性質であるが，1968 年の発売から現在に至るま で，本 ChE 阻害薬が臨床で使用され続けている理 由の 1 つである可能性がある，実際に，実験動物や ヒトにおいて，ジスチグミンの AChE 阻害作用や 重症筋無力症に対する治療効果の持続性に関して以 下の結果が報告されている：1） ジスチグミンを腹 腔内投与したラットでは，抗クラーレ作用（d-ツボ
クラリンの筋弛緩作用に対する拮抗作用）が投与 24 時間後まで観察された；35) 2) ジスチグミンを経 口投与したラットでは，赤血球，結腸，膀胱及び顎 下腺の $\mathrm{AChE}$ 活性は，投与 12 時間後においても抑 制されたままであった；28３）重症筋無力症患者に ジスチグミンを経口投与すると，症状の緩和が 36 時間にわたり認められた；2４４）ジスチグミンを投 与されたヒトの赤血球の $\mathrm{AChE}$ 阻害作用を指標と した回復半減期の推定值は約 40 時間であった. ${ }^{36)}$ これに対して，膀胱運動に対する六進作用や尿排出 機能の促進作用についてはジスチグミンの持続性に 関する研究報告がほとんどなく，シストメトリー法 を用いて麻酔下モルモットの膀胱内圧に対するジス チグミンの作用を報告した当教室からの研究報告の

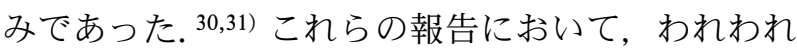
は，ジスチグミンがネオスチグミン（可逆的コリン エステラーゼ阻害薬）やベタネコール（合成コリン エステル）と比較すると作用持続時間が遥かに長い ことを見い出し，麻酔下モルモットの排尿間隔や蓄 尿時最小膀胱内圧には影響を与えずに，排尿時最大 膀胱内圧 (maximum intravesical pressure at micturi- 


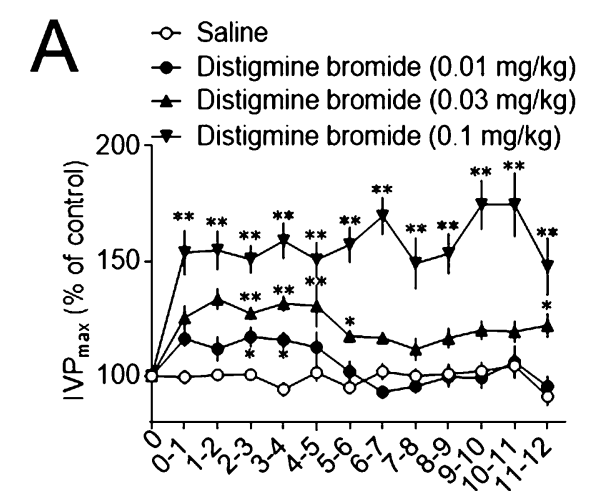

Time after administration (h)

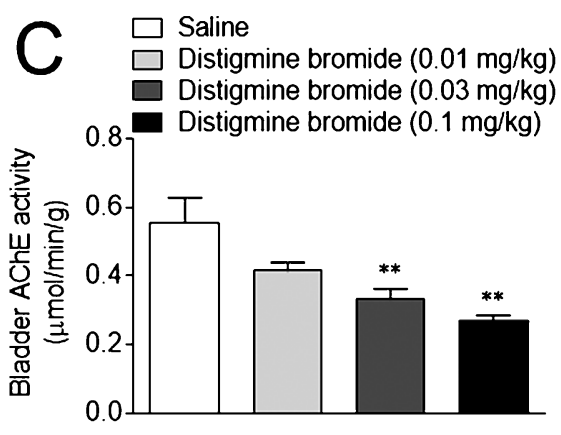

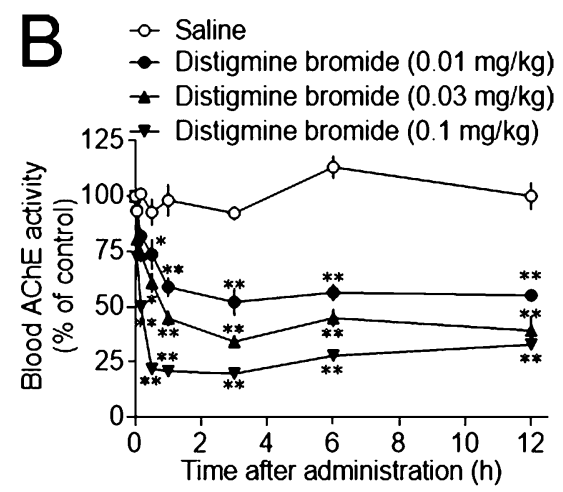

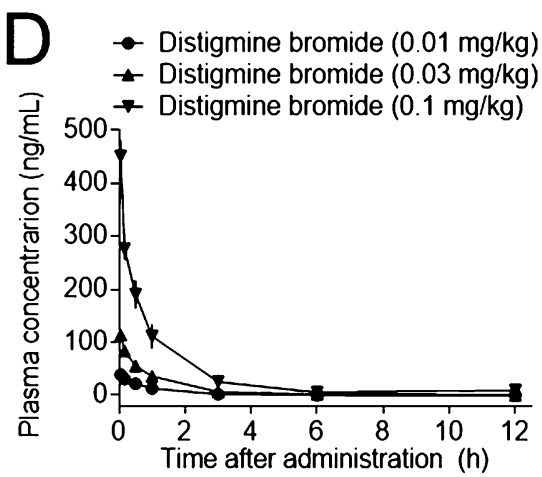

Fig. 3. Effects of Distigmine Bromide on Guinea Pig Intravesical Pressure and Blood/Urinary Bladder Acetylcholinesterase (AChE) Activities, and Time-course for Plasma Distigmine Bromide Concentration

(A) Effects of distigmine $\left(0.01-0.1 \mathrm{mg} / \mathrm{kg}\right.$, intravenous injection; i.v.) and saline on the maximum intravesical pressure at micturition reflexes (IVP $\mathrm{P}_{\max }$ ) changes for $12 \mathrm{~h}$ after their injection. (B) Blood AChE activity changes for $12 \mathrm{~h}$ after distigmine $\left(0.01-0.1 \mathrm{mg} / \mathrm{kg}\right.$, i.v.) and saline injection measured by $5,5^{\prime}-$ dithiobis (2-nitrobenzoic acid) (DTNB) method in the presence of a butyrylcholinesterase inhibitor, tetraisopropyl pyrophosphoramide (iso-OMPA, 10-6 M) . (C) Urinary bladder AChE activity $12 \mathrm{~h}$ after distigmine $(0.01-0.1 \mathrm{mg} / \mathrm{kg}$, i.v.) and saline injection measured by DTNB method in the presence of iso-OMPA $\left(10^{-6} \mathrm{M}\right)$. (D) Time-course of plasma distigmine bromide concentration measured by LC-MS/MS. Results are presented as mean \pm S.E.M. $(n=4) .{ }^{*} p<0.05$, ${ }^{* *} p<0.01 v s$. saline. Modified and reproduced with permission from Biol. Pharm. Bull. Vol. 40 No. 6 Pages 807-814. Copyright 2017 The Pharmaceutical Society of Japan.

tion reflexes; $\left.\mathrm{IVP}_{\max }\right)$ を 4 時間以上にわたり持続的 に増加させることを報告した。しかし，ジスチグミ ンの膀胱運動増強効果が 4 時間を超えてさらにどの 程度持続するのかという点についてはまだ検討され ておらず，ジスチグミンによる持続性の膀胱運動増 強効果とその体内動態, 特に血漿中濃度やさらには $\mathrm{AChE}$ 活性阻害作用との関連性についても不明のま まであった。ここでは，シストメトリー法を用い て，ジスチグミンによるモルモットの膀胱内圧増強 効果の持続性と ChE 活性阻害作用及び血漿中濃度 との関連性について検討したわれわれの実験結果 ${ }^{37)}$ について紹介する.

Figure 3(A) は，シスメトリー法を用いて測定し た麻酔下モルモットに生理食塩液又はジスチグミン (0.01-0.1 mg/kg, i.v.) を投与した際の膀胱内圧変 化について，薬物投与前の $\mathrm{IVP}_{\text {max }}$ を $100 \%$ とし て, 薬物投与後の IVP $\mathrm{max}_{\text {max }}$ の変化を薬物投与 12 時間
後まで示したものである. Figure $3(\mathrm{~A})$ に示すよう に, $0.03 \mathrm{mg} / \mathrm{kg}$ の用量では, $\mathrm{IVP}_{\max }$ の増加が 0.01 $\mathrm{mg} / \mathrm{kg}$ のそれよりも顕著になり，ジスチグミン投 与後 12 時間まで IVP max $_{\text {max }}$ が増加したままであった. $0.1 \mathrm{mg} / \mathrm{kg}$ の用量では, IVP $\operatorname{IVx}_{\max }$ の増加がさらに顕著 になり，ジスチグミン投与後 12 時間にわたり統計 的な有意差が認められた。この結果は，これまでに 長時間持続性の性質が報告されている抗クラーレ作 用 ${ }^{35)}$ や赤血球 AChE 活性阻害作用 ${ }^{36)}$ と同様に, 少 なくとも 12 時間以上にもわたるジスチグミンの長 時間持続性の性質が膀胱運動増強効果にも及ぶこと を明らかにした最初の知見である。また，Fig. 3 (B)に示すように, 血中 AChE 活性はジスチグミン の用量に依存して持続的に抑制され，ジスチグミン 投与 12 時間後においても生理食塩液投与群と比較 して統計的な有意差が認められた。 さらに，Fig. 3 (C)に示すように，ジスチグミン投与 12 時間後に 
摘出した膀胱組織の AChE 活性は，ジスチグミン 投与群のほうが生理食塩液投与群よりも低かった. なお，ジスチグミン $(0.01-0.1 \mathrm{mg} / \mathrm{kg}, \mathrm{i} . v$.$) は血漿$ ChE（ブチリルコリンエステラーゼ）活性には有意 な影響を与えなかった。 したがって，ジスチグミン の膀胱運動の増強効果 ( IVP $_{\max }$ の増加効果) は, 本 ChE 阻害薬によりもたらされる膀胱組織の $\mathrm{AChE}$ 活性の阻害を反映したものであると考えられ た.

Figure 3(D) は，シストメトリー法による膀胱内 圧の測定中にモルモットから採血して得られた血漿 を用いて，LC-MS/MS によりジスチグミンの血墏 中濃度の経時変化を測定した結果であるが，ジスチ グミン（0.01-0.1 mg/kg, i.v.）を投与すると，速や かに血漿中から消失し，投与 3 時間後には，投与 3 分後の濃度と比較すると, 血漿中から約 $95 \%$ のジ スチグミンが消失することが明らかとなった。さら に, 投与 6 時間後には，投与 3 分後の濃度と比較す ると，血漿中から約 $99 \%$ のジスチグミンが消失す ることが示された。この結果から，ジスチグミンの 膀胱運動増強効果及び AChE 阻害作用はその血漿 中濃度とは相関しない，すなわち，長時間持続性の 性質を示すジスチグミンの膀胱運動増強効果及び $\mathrm{AChE}$ 阻害作用は，血漿中からの供給がなくてもそ の薬理作用が発揮される可能性が示された。この点 に関して，Ito らは，ジスチグミンを経口投与した ラットにおいて赤血球 $\mathrm{AChE}$ 活性阻害作用と血漿 中ジスチグミン濃度に解離が生じることを報告して いる. ${ }^{28)}$ また，ジスチグミンは腎排泄型薬物である ことから, 38$)$ ジスチグミンによる長時間持続性の膀 胱運動増強効果に対する活性代謝物の影響は考慮し なくてもよいと考えらえる.さらに，われわれは 3 つのジスチグミンの分解候補物質がいずれも $\mathrm{AChE}$ 阻害作用を示さないことも明らかにしている. ${ }^{33)}$

以上のことから，ジスチグミンによる膀胱運動増 強効果が長時間にわたり持続する（膀胱組織の $\mathrm{AChE}$ 活性に対する阻害作用が長時間持続する）理 由として, ジスチグミンが膀胱平滑筋組織内に長時 間留まる，あるいは，膀胱組織の $\mathrm{AChE}$ と強固に 結合する（AChEから解離し難い）などの可能性が 考えられた。

\section{4. 膀胱平滑筋の ACh 誘発収縮に対するジスチ グミンの増強効果の持続可能性}

前項では, ジスチグミンの膀胱運動増強効果と AChE 活性阻害作用が，ジスチグミンが血漿から消 失した後も長時間にわたり持続する結果を紹介し たそその要因としては，ジスチグミンが膀胱平滑筋 細胞の形質膜も含め組織内に長時間留まる可能性や ジスチグミンが AChE と強固に結合して安定な複 合体を形成する可能性などが考えられたが，ジスチ グミンが長時間にわたり膀胱運動の増強と $\mathrm{AChE}$ の阻害をもたらす要因を絞り込むためには，摘出し た膀胱平滑筋組織を用いた検討が有効であると考え られた。なぜならば，摘出膀胱平滑筋標本を用いた 検討を行うことで，血中に存在するジスチグミンの 影響を排除できるとともに，代謝物の影響もある程 度排除できるからである。ここでは，モルモット摘 出膀胱平滑筋標本を用いて，ジスチグミンによる $\mathrm{ACh}$ 誘発性収縮反応の増強効果と膀胱組織の $\mathrm{ChE}$ 活性阻害作用が，栄養液中からジスチグミンを取り 除いた後（ジスチグミンの洗滌後），どのくらいの 時間持続するのか検討したわれわれの結果 ${ }^{33)}$ を紹介 する。併せて，他のカルバメート系 ChE 阻害薬 （ピリドスチグミン，ネオスチグミン，アンベノニ ウム）（Fig. 1）の作用持続性と比較検討した結果 も紹介する.

Figures 4(B)-(D) は，ACh $\left(3 \times 10^{-6} \mathrm{M}\right)$ による モルモット膀胱平滑筋標本の収縮反応に対するピリ ドスチグミン，ネオスチグミン，アンベノニウム （それぞれ $10^{-6} \mathrm{M}$ ）の増強効果と薬物洗滌後の増強 効果の持続性を 12 時間後まで検討した実験の代表 的なトレースである。これら 3 つの $\mathrm{ChE}$ 阻害薬は,

$\mathrm{ACh}$ の投与 30 分前に処置しておくと ACh による 収縮反応を著明に増強したが，これらの増強効果は 阻害薬洗滌後 2-3 時間以内に消失した。これに対し て，ジスチグミンは洗沙 12 時間後まで ACh によ る収縮反応を有意に増強したままであることを明ら かにしたが，ジスチグミン $\left(10^{-6} \mathrm{M}\right)$ 洗滌後の増 強効果の持続性を洗滌 40 時間後まで検討したとこ ろ，洗滌 40 時間後においてもその効果は持続して いることを確認することができた [Fig. 4(A)]。な お，膀胱平滑筋以外の平滑筋組織でもジスチグミン が持続的な効果を発揮するか検討するため, モル モット回腸縦走筋を用いて $\mathrm{ACh}\left(10^{-7} \mathrm{M}\right)$ による 

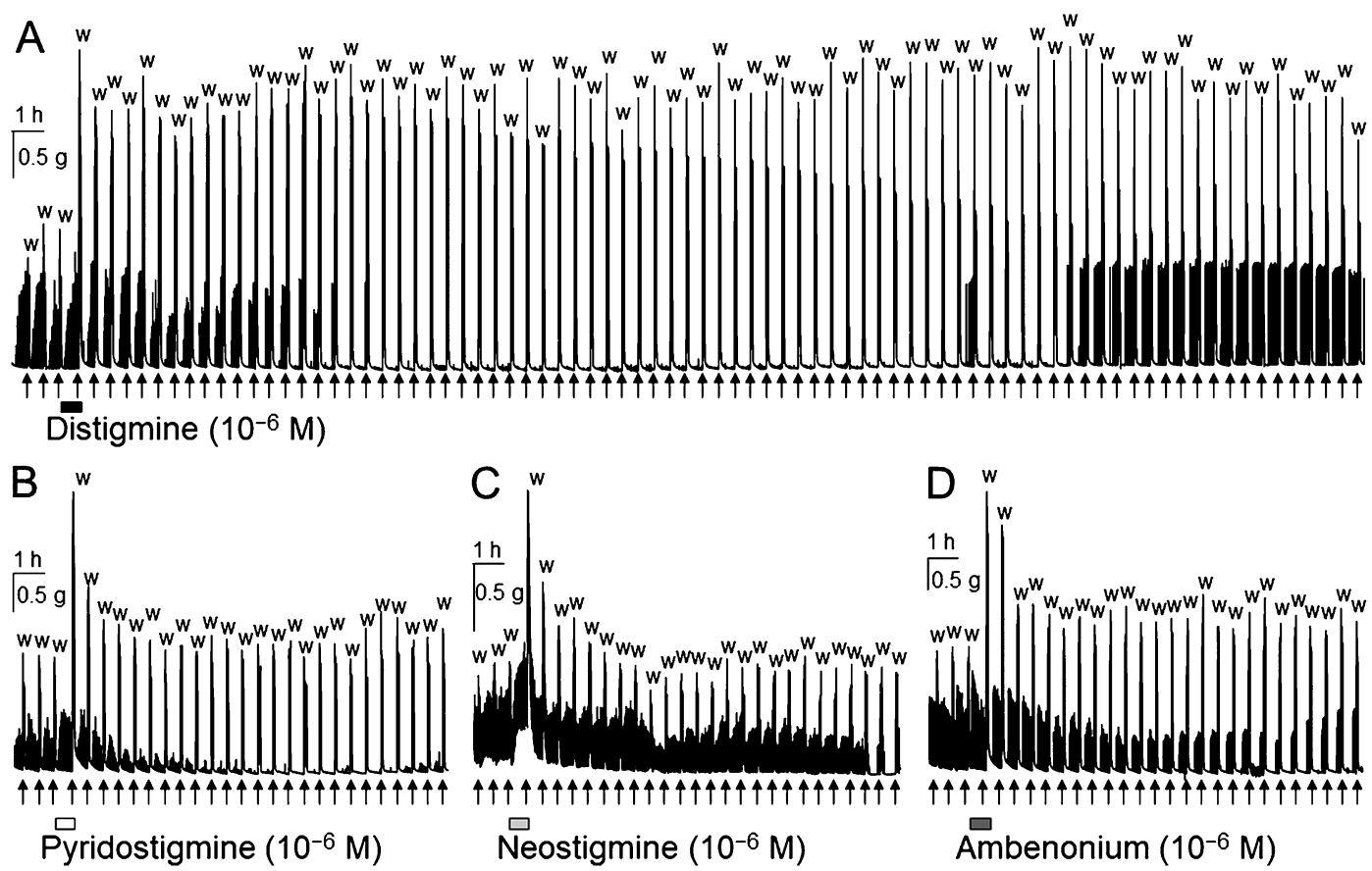

Fig. 4. Effects of Distigmine, Pyridostigmine, Neostigmine, and Ambenonium on $3 \times 10^{-6} \mathrm{M}$ ACh-induced Contraction in Guinea

Pig Urinary Bladder Smooth Muscle after Their Washout

(A) A representative trace of the potentiating effects of distigmine $\left(10^{-6} \mathrm{M}\right)$ on $3 \times 10^{-6} \mathrm{M}$ ACh-induced contraction up to $40 \mathrm{~h}$ after its washout. (B) $-(\mathrm{D})$ Representative traces of the potentiating effects of pyridostigmine (B), neostigmine (C), and ambenonium (D) (each $10^{-6} \mathrm{M}$ ) on $3 \times 10^{-6} \mathrm{M}$ ACh-induced contraction up to $12 \mathrm{~h}$ after their washout. Arrow: administration of $3 \times 10^{-6} \mathrm{M}$ ACh. w: washout. (B) $-(\mathrm{D})$ Modified and reproduced with permission from Biol. Pharm. Bull. Vol. 40 No. 7 Pages 1092-1100. Copyright 2017 The Pharmaceutical Society of Japan.

収縮反応に対するジスチグミン，ピリドスチグミン （それぞれ $10^{-6} \mathrm{M}$ ) の増強効果と薬物洗滌後の増強 効果の持続性を 12 時間後まで検討したが，回腸縦 走筋においても膀胱平滑筋と同様に，洗滌後 12 時 間後までジスチグミンの増強効果が持続しままで あった（Fig. 5)。なお，モルモット膀胱平滑筋標 本の $\mathrm{ChE}$ 活性に対する各種 $\mathrm{ChE}$ 阻害薬の影響も検 討したが，ジスチグミンを除く 3 つの ChE 阻害薬 （ネオスチグミン，ピリドスチグミン，アンベノニ ウム）の ChE 阻害作用は，阻害薬洗滌後に時間依 存的に回復し，ジスチグミンの ChE 活性阻害作用 は洗滌 12 時間後まで持続したままであった.

したがって，ジスチグミンの作用のみが洗滌後も 特筆すべき持続性を示した理由として, ジスチグミ ンが血中に長時間留まるからではなく，本 $\mathrm{ChE}$ 阻 害薬が ChE に強固に結合して解離し難いジスチグ ミンーChE 複合体を形成した可能性が考えられた.

\section{5. $\operatorname{rhAChE}$ に対するジスチグミンの阻害効果の} 持続性

前項ではジスチグミンが長時間にわたり排尿時最 大膀胱内圧を増強させる機構として, ジスチグミン
が ChE（AChE）に強固に結合して解離し難い可能 性と, ジスチグミンが形質膜に留まり長時間にわた り ChE（AChE）に供給される可能性を想定した. このうち前者の可能性を想定し, 摘出膀胱平滑筋標 本の ChE 活性を測定したところ，ジスチグミンは その洗滌後でも少なくとも 12 時間にわたり $\mathrm{ChE}$ を 阻害し続けることを見い出した。しかし，この結果 は平滑筋組織標本を用いた検討により得られたもの であるため，後者の可能性を完全には排除できな かった。ここでは，ジスチグミンが AChE に直接 作用することで長時間にわたりその酵素活性を阻害 することを示すより直接的な証拠を得る目的で, $\mathrm{rhAChE}$ を用いて生化学的な検討（解離半減期の算 出）を行ったわれわれの結果 ${ }^{39)}$ を紹介する.

まず，われわれが行ったジスチグミンの rhAChE に対する解離速度定数の測定法について簡潔に述べ る。本測定では，Fig. 6 に示すように，Nanosep ${ }^{\circledR}$ $10 \mathrm{~K}$ 遠心デバイスを利用することにより，ChE 阻 害薬処置後に限外ろ過により $\mathrm{rhAChE}$ と末反応の $\mathrm{ChE}$ 阻害薬を分離した。すなわち，万過膜上に $\mathrm{AChE}$ が残り，ろ液中に未反応の $\mathrm{ChE}$ 阻害薬が移 

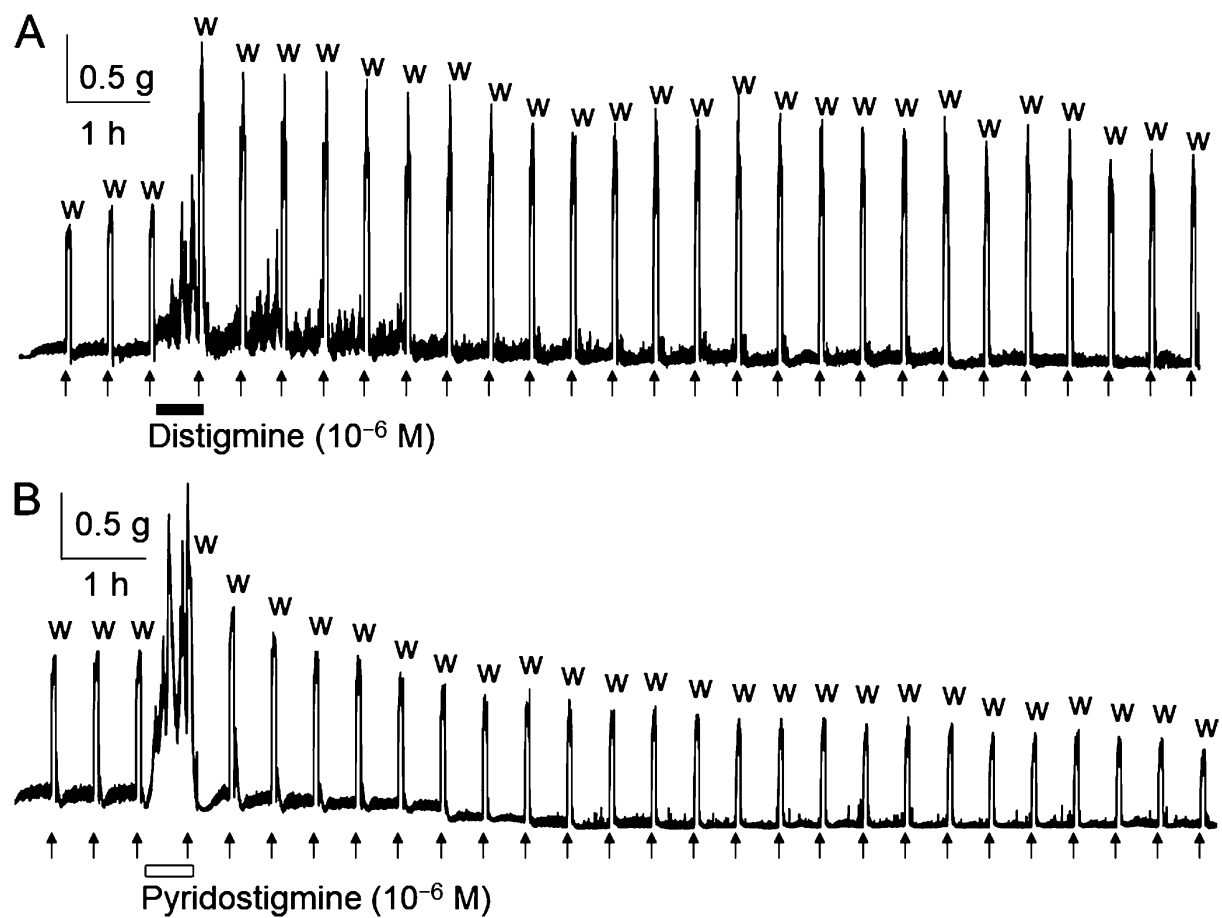

Fig. 5. Effects of Distigmine (A), Pyridostigmine (B) on $10^{-7} \mathrm{M}$ ACh-induced Contraction in Guinea Pig Ileal Longitudinal Smooth Muscle up to $12 \mathrm{~h}$ after Their Washout

Arrow: administration of $10^{-7} \mathrm{M}$ ACh. w: washout.

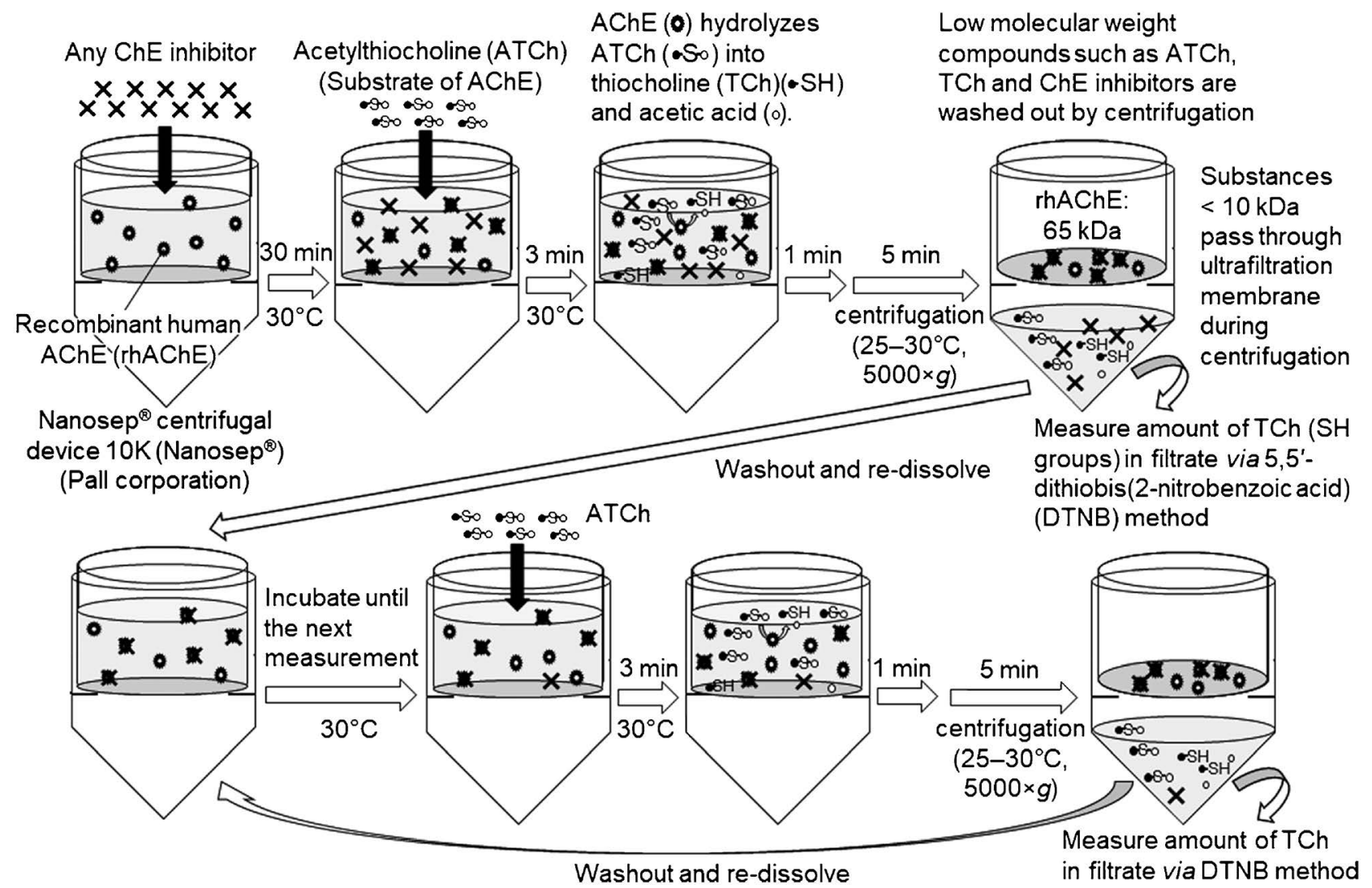

Fig. 6. Basic Principle of Measuring Recombinant Human AChE (rhAChE) Activity Using a Nanosep ${ }^{\circledR} 10 \mathrm{~K}$ Centrifugal Device Modified and reproduced with permission from Biol. Pharm. Bull., Vol. 40 No. 10, Pages 1739-1746. Copyright 2017 The Pharmaceutical Society of Japan. 

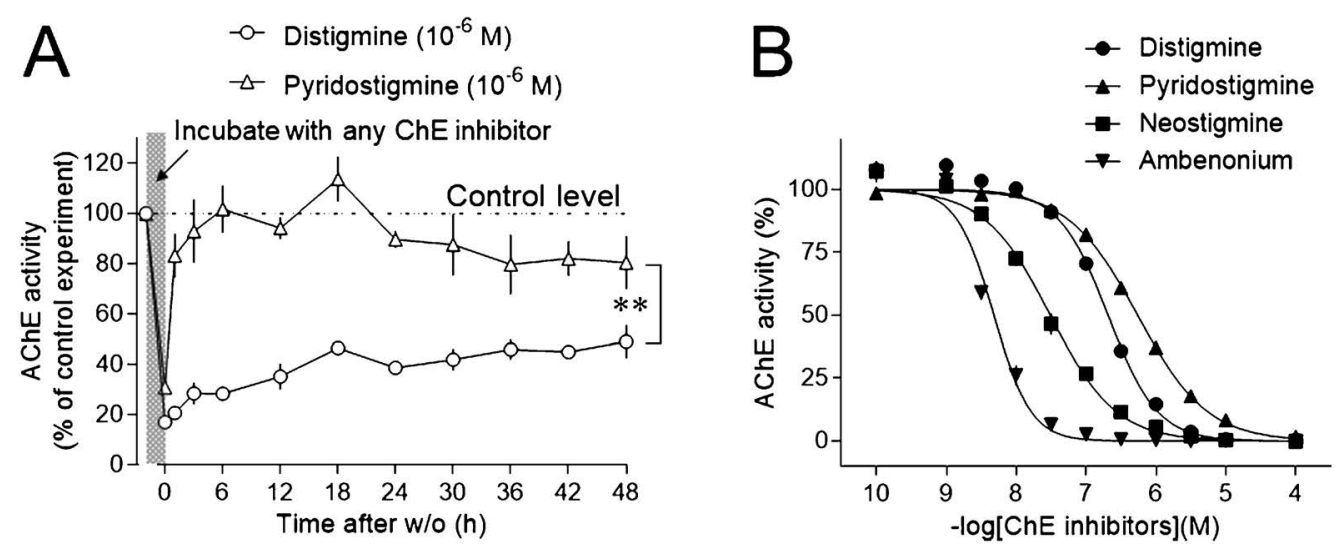

Fig. 7. Effects of ChE Inhibitors on Recombinant Human AChE (rhAChE) Activity

(A) Effects of distigmine, and pyridostigmine (each $10^{-6} \mathrm{M}$ ) on rhAChE activity up to $48 \mathrm{~h}$ after their washout (w/o). Results are presented as mean \pm S.E.M. $(n=3)$. ${ }^{* *} p<0.01$ at $48 \mathrm{~h}$ after w/o. (B) Concentration-response curves for inhibitory effects of distigmine, pyridostigmine, neostigmine, and ambenonium on rhAChE activity. Results are presented as mean \pm S.E.M. $(n=4-5)$. Modified and reproduced with permission from Biol. Pharm. Bull., Vol. 40 No. 10, Pages 1739-1746. Copyright 2017 The Pharmaceutical Society of Japan.

行することで結合反応を終了させ，解離反応を選択 的に進行させる条件下で測定することで，ジスチグ ミン及びその他の ChE 阻害薬の rhAChE からの解 離半減期を算出した. Figure 7(A)は，上記の方法 を用いて行ったジスチグミン，ピリドスチグミン処 置後の rhAChE の活性とこれら阻害薬の洗滌 48 時 間後までの AChE の活性の経時変化を示す。ピリ ドスチグミン $\left(10^{-6} \mathrm{M}\right)$ の処置により低下した rhAChE の活性は，洗滌後徐々に回復し，6 時間後 の時点で完全に回復したのに対し，ジスチグミン $\left(10^{-6} \mathrm{M}\right)$ を処置した $\mathrm{rhAChE}$ の活性は，ゆっくり と回復はしたものの，洗條 48 時間後においてもピ リドスチグミンを処置した rhAChE と比較してそ の活性が有意に阻害されたままであった。なお，本 実験結果から算出したジスチグミンの rhAChE か らの解離半減期は 57.8 時間となった。また，ネ才 スチグミン及びアンベノニウムもピリドスチグミン と同様に，洗滌操作により，AChE 活性阻害効果が 徐々に消失していくことを確認し，ピリドスチグミ ン，ネオスチグミン，アンベノニウムの rhAChE からの解離半減期はそれぞれ，1.36 時間，1.05 時 間， 0.49 時間となった.

これらの結果は，ジスチグミンが AChE に直接 作用することで長時間にわたりその酵素活性を阻害 し, 他の ChE 阻害薬と比較して AChE から解離し 難い（非常にゆっくり解離する）ことを示すもので ある．この理由としては，ジスチグミンがその構造 中に長鎖アルキル基を有すること（Fig. 1）が原因
である可能性が考えられる。この点について Perola らは最初に見い出された ChE 阻害薬であるフィ ゾスチグミンに長鎖アルキル基を導入した物質の解 離速度定数は，フィゾスチグミン自身の解離速度定 数に比べて非常に小さくなることを報告し，この原 因を，長鎖アルキル基の導入により脱カルバモイル 化を進行させる水分子が $\mathrm{AChE}$ の活性部位に近づ

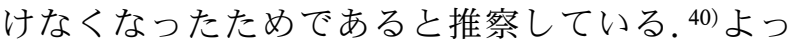
て，ジスチグミンがもつ長鎖アルキル基により水分 子を介した解離反応が妨げられる結果，他の $\mathrm{ChE}$ 阻害薬と比較して 40-120 倍 AChE から解離し難い 性質を示すようになると推察される，なお，Fig. 7 （B）に示すように, $\mathrm{pIC}_{50}$ 值に基づいた各種 $\mathrm{ChE}$ 阻 害薬の AChE に対する親和性の順位は，アンベノ ニウム >ネオスチグミン>ジスチグミン >ピリド スチグミンの順となったことから，AChEに対する ジスチグミンの解離半減期が他の ChE 阻害薬のそ れよりもはるかに大きい理由として，ジスチグミン が他の ChE 阻害薬よりも AChE に対して高い親和 性を有する可能性は排除してよいものと考えられた.

\section{6. まとめ}

ジスチグミンは, AChE 阻害作用により, 膀胱平 滑筋での副交感神経伝達物質のうち，ATP による 収縮反応には影響を与えずに，ACh による収縮反 応を選択的に増強し，血中から消失した後も極めて 長時間にわたり膀胱運動の増強効果と膀胱組織 $\mathrm{AChE}$ の阻害作用を示す。これらの持続的な作用 は，ジスチグミンが AChE から極めて解離し難い 
性質により生じ，この性質が低活動膀胱治療薬とし て長時間にわたり膀胱運動を増強する機序の一端を 担い, 1968 年の発売から現在に至るまで，本 ChE 阻害薬が臨床で使用され続けている理由の 1 つであ ると考えられる，ただし，日本では，低活動膀胱の 治療には，1 日 1 回 $5 \mathrm{mg}$ のジスチグミンを経口投 与することが一般的であるが，ドイツの添付文書で は，最初の数日間は 1 日 1 回 $5 \mathrm{mg}$ を経口投与し， その後，2 日又は 3 日毎に 5-10 mg の経口投与で効 果が維持できると記載されている. ${ }^{41)}$ われわれが算 出したジスチグミンの解離半減期が 57.8 時間であ ることを考慮すると，後者の使用方法の方が理にか なっており，ジスチグミンの副作用であるコリン作 動性クリーゼを回避する観点からも使用方法につい ては一考の余地があると思われる.

利益相反＼cjkstart開示すべき利益相反はない.

\section{REFERENCES}

1) Schmid O., U.S. Patent 2789981 (1957) .

2) Pateisky K., Wien. Z. Nervenheilkd. Grenzgeb., 17, 53-84 (1959).

3) Emeryk E., Wasowicz B., Neurol. Neurochir. Psychiatr. Pol., 13, 611-617 (1963).

4) Ishigaki K., Murakami T., Ito Y., Yanagisawa A., Kodaira K., Shishikura K., Suzuki H., Hirayama Y., Osawa M., No To Hattatsu, 41, 37-42 (2009).

5) "Martindale: The Complete Drug Reference, Antimyasthenics," 39th ed., ed. by Brayfield A., Pharmaceutical Press, London, 2017, pp. 694-700.

6) Ishikawa S., Tsukahara S., Sato Y., Ophthalmologica, 159, 339-362 (1969) .

7) Mizukawa T., Azuma I., Nihon Ganka Kiyo, 21, 586-595 (1970).

8) Sawada A., Hara K., Futa R., Ogata H., Nihon Ganka Kiyo, 22, 676-682 (1971).

9) Cameron M. D., J. Obstet. Gynaecol. Br. Commonw., 73, 847-848 (1966).

10) Yeo J., Southwell P., Hindmarsh E., Med. J. Aust., 1, 116-120 (1973).

11) Smith P. H., Cook J. B., Prasad E. W., Br. J. Urol., 46, 187-192 (1974).

12) Yeo J., Southwell P., Rutowski S., MarchantWilliams H., Med. J. Aust., 2, 201-203
(1974).

13) Oka N., Hasegawa S., Hinyokika Kiyo, 13, 42-51 (1967).

14) Philp N. H., Thomas D. G., Br. J. Urol., 52, 492-496 (1980).

15) Tanaka Y., Masumori N., Itoh N., Furuya S., Nishizawa O., Tsukamoto T., Urology, 57, 270-274 (2001).

16) Bougas D. A., Mitsogiannis I. C., Mitropoulos D. N., Kollaitis G. C., Serafetinides E. N., Giannopoulos A. M., Int. Urol. Nephrol., 36, 507-512 (2004) .

17) Yamanishi T., Yasuda K., Kamai T., Tsujii T., Sakakibara R., Uchiyama T., Yoshida K., Int. J. Urol., 11, 88-96 (2004) .

18) Tanaka Y., Masumori N., Tsukamoto T., Furuya S., Furuya R., Ogura H., Adv. Urol., 782985 (2009).

19) Skolarikos A., Tyritzis S., Stamatiou K., Minerva Urol. Nefrol., 64, 209-216 (2012) .

20) Sugaya K., Kadekawa K., Onaga T., Ashitomi K., Mukouyama H., Nakasone K., Shimabukuro H., Shimabukuro S., Matayoshi Y., Hokama S., Touyama Y., Nishijima S., Nihon Hinyokika Gakkai Zasshi, 105, 10-16 (2014).

21) Izumi K., Maolake A., Maeda Y., Shigehara K., Namiki M., Minerva Urol. Nefrol., 66, 241-247 (2014) .

22) Eto R., Naganuma H., Fuji I., Kyushu Neuropsych., 34, 308-311 (1988).

23) Tsuno N., Miyata H., Nakayama K., Brain Sci. Mental Disorders, 14, 149-153 (2003).

24) Katsumi T., Murayama K., Hinyokika Kiyo, 38, 1089-1092 (1992).

25) Shibayama K., Makino T., Machida M., Hatori M., Jpn. Pharmacol. Ther., 20, 38393843 (1992).

26) Mikami Y., Araki I., Maezawa H., Takeda M., Jpn. J. Urol. Surg., 20, 1207-1213 (2007) .

27) Burnstock G., Purinergic Signal., 10, 103-155 (2014) .

28) Ito Y., Harada T., Fushimi K., Kagawa Y., Oka H., Nakazawa H., Homma R., Kato Y., Yamada S., Drug Metab. Pharmacokinet., 25, 254-261 (2010).

29) Obara K., Kobayashi Y., Chino D., Tanaka Y., Eur. J. Pharmacol., 809, 209-214 (2017). 
30) Sekiya S., Takahashi H., Seki Y., Teraoka A., Aikawa N., Tanaka Y., Koike K., Pharmacometrics, 75, 85-96 (2008).

31) Obara K., Aikawa N., Sato K., Chino D., Tanaka Y., Pharmacometrics, 85, 101-114 (2013).

32) Horinouchi T., Aoki T., Akiyama R., Ono T., Shibano M., Tanaka Y., Koike K., Pharmacometrics, 64, 45-52 (2003).

33) Obara K., Ogawa T., Chino D., Tanaka Y., Biol. Pharm. Bull., 40, 1092-1100 (2017).

34) Obara K., Kobayashi Y., Chino D., Tanaka Y., Pharmacology, 99, 106-113 (2017).

35) Herzfeld E., Kraupp O., Pateisky K., Stumpf C., Wien. Klin. Wochenschr., 69, 245-248 (1957).
36) Breuel H. P., Bohn-Olszewsky W., Engelsen S. J., Samhaber E. M., Niklaus H., Int. J. Clin. Pharmacol. Ther. Toxicol., 31, 230-235 (1993).

37) Obara K., Chino D., Tanaka Y., Biol. Pharm. Bull., 40, 807-814 (2017).

38) Vree T. B., Waitzinger J., Hammermaier A., Radhofer-Welte S., Int. J. Clin. Pharmacol. Ther., 37, 393-403 (1999).

39) Obara K., Chino D., Tanaka Y., Biol. Pharm. Bull., 40, 1739-1746 (2017).

40) Perola E., Cellai L., Lamba D., Filocamo L., Brufani M., Biochim. Biophys. Acta, 1343, 41-50 (1997).

41) Fachinformation for Ubretid ${ }^{\circledR}$ tablet provided by Takeda GmbH (Konstanz), 2018. 